\title{
Clinical Profile of Foot Gangrene and Its Outcome in a Rural Medical College
}

\author{
Brinda Maheswari Murugiah ${ }^{1}$, Anvar Ali Abdul Haium², Ashok Swaminathan Govindarajan³, \\ Ravisankar Prakash ${ }^{4}$, Prema Mariappan ${ }^{5}$, Prem Kumar Thirusangu ${ }^{6}$, Mohamed Fazal Avwar Basha ${ }^{7}$ \\ 1, 2, 4, 5, 6,7 Department of Surgery, Rajah Muthiah Medical College and Hospital, Annamalai \\ Nagar, Chidambaram, Tamilnadu, India. ${ }^{3}$ Department of Plastic Surgery, Rajah Muthiah \\ Medical College and Hospital, Annamalai Nagar, Chidambaram, Tamilnadu, India.
}

\section{ABSTRACT}

\section{BACKGROUND}

Gangrene refers to the dead or dying body tissue (s) that occurs because the local blood supply to the tissue is either lost or is inadequate to keep the tissue alive. Foot gangrene is becoming a major concern which changes the quality of life, and also the social and economic point of view. We wanted to study the clinical profile of foot gangrene, determine the most common aetiology, distribution of age and sex, presentation, associated risk factors, commonest organisms involved, ways to find and manage the complications, and study the outcomes of foot gangrene in a rural medical college.

\section{METHODS}

Clinical profiles of all 50 patients with foot gangrene were studied as a prospective observational study in a rural medical college from October 2018 to October 2020. All cases were evaluated by history, clinical examination, investigations, management and follow up.

\section{RESULTS}

Our study involved 50 patients; youngest patient was 33 years and oldest was 70 years. Majority of patients with foot gangrene were in the age group of 41 - 50 years, (22 cases) and highest number were males, (37 cases). Diabetes mellitus is the commonest aetiology accounting for 30 cases and commonest risk factor that confounds the disease process is smoking (17 cases). The commonest presentation was blackish discoloration of toe ( $\mathrm{s}$ ) along with cellulitis and ulceration (30 cases). The commonest organism isolated from culture is methicillin resistant Staphylococcal aureus (MRSA) (13 cases). Majority of the patients underwent Ray's amputation (16 cases) in our study and majority had no post-operative wound complication (28 cases) within the minimum follow up period of 6 months.

\section{CONCLUSIONS}

We have therefore attempted in our study, to analyse the gangrene of the foot since diabetic cases and trauma cases are more in the rural setup and treatment of these gangrene cases is a challenging task as well.

\section{KEY WORDS}

Foot Gangrene, Amputation, Diabetes Mellitus
Corresponding Author: Dr. Brinda Maheswari Murugiah, Room No - 106, Womans Health Professional Hostel, Annamalai Nagar, Chidambaram- 608002, Tamilnadu, India.

E-mail: brindamaheswari.bm@gmail.com

DOI: $10.14260 /$ jemds/2021/107

How to Cite This Article:

Murugiah BM, Haium AAA, Govindarajan $A S$, et al. Clinical profile of foot gangrene and its outcome in a rural medical college.J Evolution Med Dent Sci 2021;10(08):488492, DOI: 10.14260/jemds/2021/107

Submission 21-10-2020,

Peer Review 26-12-2020,

Acceptance 31-12-2020,

Published 22-02-2021.

Copyright (C) 2021 Brinda Maheswari Murugiah et al. This is an open access article distributed under Creative Commons Attribution License [Attribution 4.0 International (CC BY 4.0)] 


\section{BACKGROUND}

The word gangrene derived from the Latin word 'gangraena' and from the Greek 'gangraina', means "putrefaction of tissues". It refers to macroscopic death of tissues or portions of tissue, which turns black and dark due to the breakdown of the haemoglobin to iron sulphide compound. ${ }^{1}$ The foot is typically considered as a "functional unit". It has two important functions, to support the body weight (static foot) and serves to propel the body forward in walking and running (dynamic foot) which is the biomechanical viewpoint. The skeleton of the foot from behind forward consists of the tarsals, metatarsals and phalanges.

The incidence of wet gangrene in recent studies shows a range from $31.3 \%$ to $35.7 \% .^{2,3}$ The common causes of foot gangrene include diabetes (neuropathy / microangiopathy / macroangiopathy), vascular, traumatic, infections. The most common sites to be affected in gangrene are the digits (fingers and toes) in lower limb and other extremities (hand, arms, feet and legs). Nowadays, many treatment modalities ranging from conservative management, sepsis control and surgical options like slough excision with skin cover, amputation of the involved gangrenous part with or without grafting, debridement and dressing have been used to treat the foot gangrene. But our major aim is to salvage the limb for the better quality of life of the patient. Treatment of risk factors are also equally important to prevent further progression of the disease and also long-term morbidity of the patient.

For a proper treatment of patients with lower limb gangrene, it is important to be aware of different causes of foot gangrene. Moreover, foot gangrene forms a good bulk of patients in our hospital. We have therefore attempted in our study, to analyse foot gangrene since diabetic cases and trauma cases are more in the rural setup. Treatment of these gangrene forms a challenging task as well.

\section{Objectives}

- To study the clinical profile of foot gangrene in a rural medical college.

- To analyse the most common aetiology, distribution of age and sex, presentation, associated risk factors and commonest organism involved in foot gangrene.

- To study the methodology to effectively manage and to find the complications and outcome of foot gangrene.

\section{METHODS}

A prospective observational study was conducted on 50 patients with foot gangrene admitted in rural medical college from October 2018 to October 2020. The cases were evaluated by history, clinical examination, investigations, management and follow up.

\section{Inclusion Criteria}

- Age above 12 years who are willing for the study.

- Patients with both dry and wet gangrene were included.
- Patients with acute and chronic presentations were included.

\section{Exclusion Criteria}

- Pregnant females.

- Patients under chemotherapy treatment, radiation therapy and steroids.

- Patients with infections like human immunodeficiency virus (HIV) and hepatitis B surface antigen (HBsAg).

- Patients who were severely moribund.

- Patients with upper limb gangrene.

\section{Statistical Analysis}

After collecting the data, values were entered into Microsoft Excel spread sheet and quantitative statistical analysis was checked by chi-square test and were performed with SPSS software version 21. Statistical values less than 0.05 were significant.

\section{RESULTS}

Gangrene refers to focal or extensive tissue death of skin and underlying tissues. It is a slow gradual process that affects the lower limb extremities (toes and feet) due to reduced blood supply to the tissues. ${ }^{4}$ In our study, clinical history of 50 patients who presented with foot gangrene was obtained and further investigated for blood investigations, arterial Doppler study, x-ray of the involved limb, cardiac evaluation with electrocardiogram (ECG) and ECHO \& ankle-brachial pressure index (ABPI). Various aetiologies have been identified, distribution and correlation between aetiologies and investigations are charted.

In our study involving 50 patients, youngest patient was 33 years and oldest was 70 years as per the age limit in our inclusion criteria. Highest number of cases was found in the age group of 41 - 50 years, 22 cases ( $44 \%$ ) followed by 13 cases (26\%) among $61-70$ years. Out of 50 patients, 37 (74 $\%$ ) cases were males and 13 (26\%) cases were females.

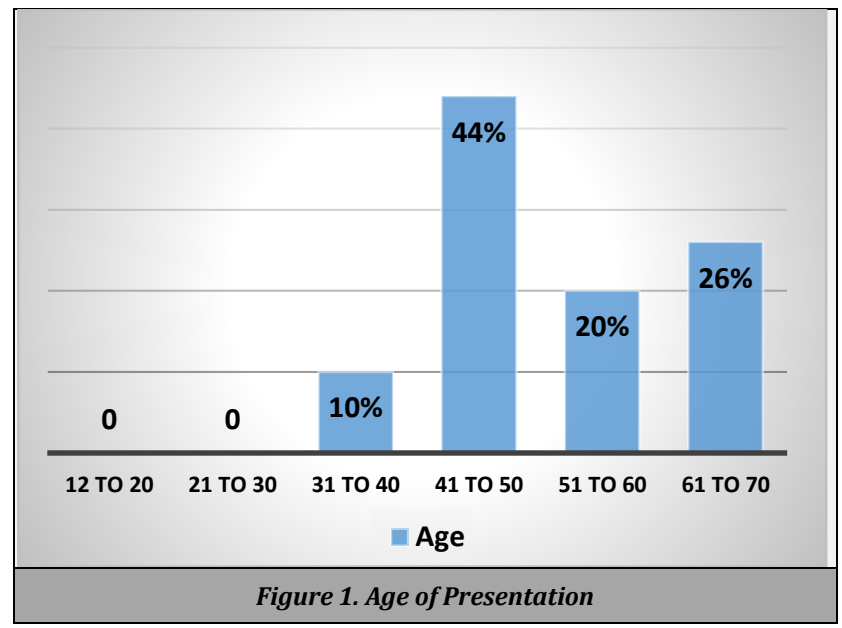

Gangrene of foot / toes was the most common presentation in $30(60 \%)$ cases. The remaining cases presented with ulceration, 14 (28\%) cases and 6 (12\%) 
patients with abscess. Though there were many causes for foot gangrene, long standing diabetes mellitus was the most common cause, $60 \%$ (30 cases) resulted due to vascular (micro / macroangiopathy), neuropathy and infections followed by vascular aetiology which constitutes $24 \%(12$ cases) and the remaining $16 \%$ (8 cases) as trauma. Out of 22 cases in the age group of 41 - 50 years, 15 cases (68\%) were found to be diabetic. Though there were plenty of risk factors, smoking was the predominant risk factor in 17 cases (34\%) followed by anaemia 10 cases (20\%) and the least common risk factor was dyslipidaemia 3 cases (6\%).

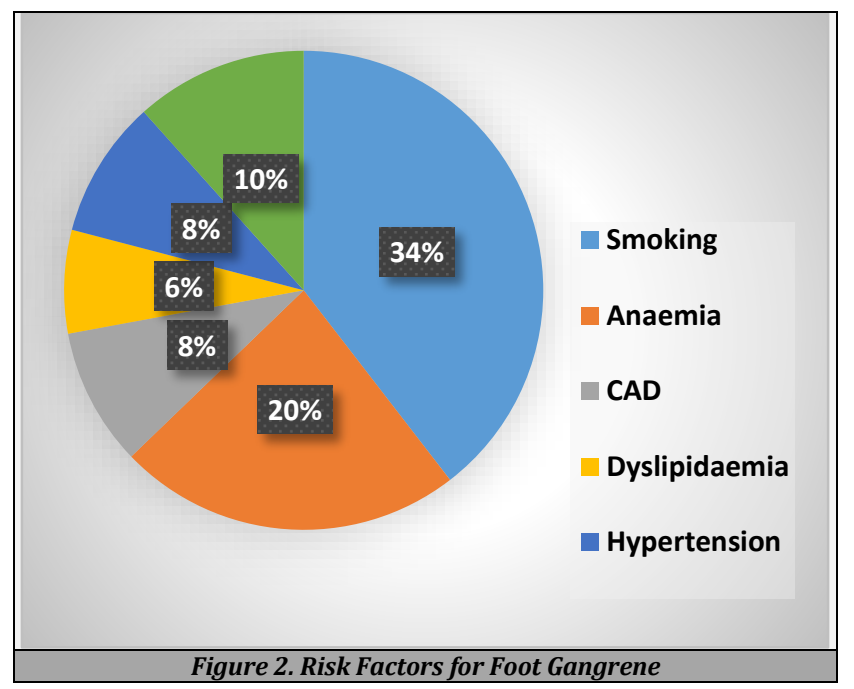

On examining peripheral pulse in dorsalis pedis, $48 \%$ had normal pulse, $22 \%$ patients had feeble pulse and $30 \%$ were found to have absent pulse which was correlated and confirmed by ABPI and Doppler study. Blood investigations revealed 44 patients ( $88 \%$ ) had abnormal blood sugar levels and, 37 (74\%) patients had raised HbA1C levels which implies uncontrolled diabetes, followed by 5 prediabetic cases (10\%) with range between 5.7 - $6.5 \% ; 34 \%$ (17 cases) presented with moderate anaemia and $16 \%$ (11 cases) presented with severe anaemia. Out of 13 females, 7 cases (53\%) were anaemic compared to 37 males in whom 9 cases $(24 \%)$ were anaemic.

Though Staphylococcus aureus is common among the skin infections, for our surprise our pus culture and sensitivity yielded MRSA in about 13 cases (26\%) in the $1^{\text {st }}$ week of study and subsequently klebsiella 11 cases (22\%), pseudomonas 9 cases (18\%), Escherichia coli [E. coli] 7 cases $(14 \%)$ and proteus 4 cases ( $8 \%)$.

Our study showed the x-ray of the limb involved was normal without any osteomyelitis or fracture in $88 \%$ and osteomyelitis present in $12 \%$ cases.

Based on the values measured from ABPI, 33 cases (66\%) were within the normal range of 0.9 to 1.2 and 7 cases ( $4 \%$ ) with values less than 0.5 that is severe arterial disease. One patient had value of 1.3 and the Doppler study confirmed atherosclerotic changes with calcifications.

In this study based on the details collected from the arterial Doppler of the involved limb $54 \%$ of cases were found to be with normal triphasic flow, $20 \%$ presented with atherosclerosis, $16 \%$ with stenosis and $10 \%$ presented with occlusion of the arteries.

Rays amputation is the common treatment in 16 cases (32 $\%$ ) followed by the Ray's amputation with split skin grafting
(SSG), in 12 cases (24\%). Each of $10 \%$ (5 cases), had debridement followed by SSG and conservative treatments and majority had no post-operative wound complication, 28 cases (56\%) were within the minimum follow up period of 6 months. Non healing of the wound was noted in 11 cases $(22$ $\%)$ and infections like slough, purulent discharge over the wound were noted in 8 cases $(16 \%)$.

On comparing between risk factors and aetiologies, among smoker's, (58.8\%) majority had vascular problems and considerable proportions, (35.3\%) had diabetes mellitus. In patients associated with anaemia, $70 \%$ had diabetes mellitus. All the patients with the risk factor of coronary artery disease (CAD), had associated diabetes mellitus. In patients with dyslipidaemia, $66.7 \%$ had diabetes and $33.3 \%$ had vascular problems. All the patients with hypertension had associated diabetes mellitus and was statistically significant.

\begin{tabular}{|c|c|c|c|c|c|c|c|}
\hline \multirow{2}{*}{$\begin{array}{c}\text { Risk } \\
\text { Factors }\end{array}$} & \multicolumn{2}{|c|}{ DM } & \multicolumn{2}{|c|}{ Trauma } & \multicolumn{2}{|c|}{ Vascular } & \multirow[t]{2}{*}{ Total } \\
\hline & $\begin{array}{l}\text { No. of } \\
\text { Cases }\end{array}$ & $\%$ & $\begin{array}{l}\text { No. of } \\
\text { Cases }\end{array}$ & $\%$ & $\begin{array}{l}\text { No. of } \\
\text { Cases }\end{array}$ & $\%$ & \\
\hline Smoking & 6 & 35.3 & 1 & 5.9 & 10 & 58.8 & 17 \\
\hline Anaemia & 7 & 70 & 2 & 20 & 1 & 10 & 10 \\
\hline CAD & 4 & 100 & - & - & - & - & 4 \\
\hline Dyslipidaemia & 2 & 66.7 & - & - & 1 & 33.3 & 3 \\
\hline Hypertension & 4 & 100 & - & - & - & - & 4 \\
\hline $\begin{array}{l}\text { Uncontrolled } \\
\text { DM }\end{array}$ & - & - & 5 & 100 & - & - & 5 \\
\hline Nil & 7 & 100 & - & - & - & - & 7 \\
\hline Total & 30 & 60 & 8 & 16 & 12 & 24 & 50 \\
\hline $\begin{array}{c}\text { Test of } \\
\text { significance }\end{array}$ & & Value & & & & & \\
\hline $\begin{array}{l}\text { Chi square } \\
\text { test }\end{array}$ & & 49.35 & & & & & \\
\hline
\end{tabular}

On comparing aetiology with arterial Doppler study, most of the patients with normal Doppler findings were associated with diabetes mellitus, $77.8 \%$ and $22.2 \%$ of them had traumatic causes. Most of the patients, $80 \%$ with atherosclerosis were associated with diabetes mellitus and 20 $\%$ of them had traumatic causes. All the patients with stenosis had vascular causes and most of the patients with occlusion were associated with vascular aetiology.

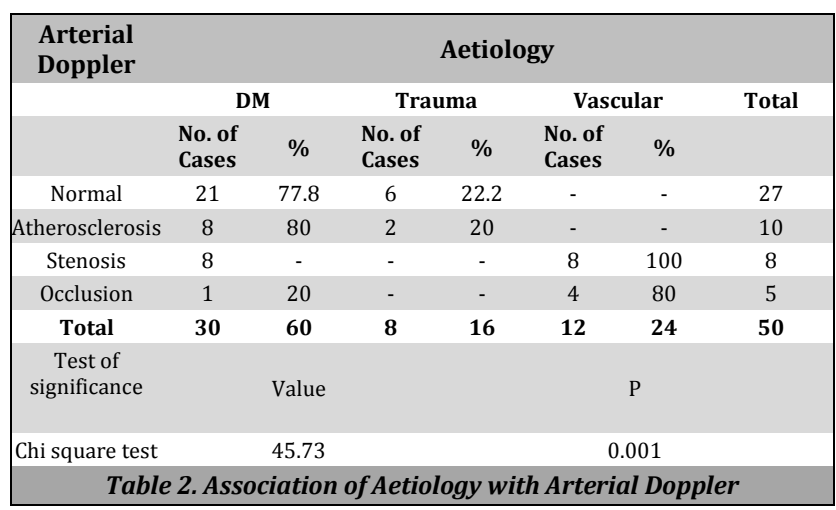

\section{DISCUSSION}

The present study was conducted among the patients with foot gangrene in various units of Department of General Surgery. A total of 50 patients were evaluated in the study. 


\begin{tabular}{|c|c|c|}
\hline Factors & Other Study & $\begin{array}{l}\text { Present Study } \\
(\mathrm{N}=50)\end{array}$ \\
\hline $\begin{array}{l}\text { Age group } \\
(41-50 \text { years })\end{array}$ & $\begin{array}{c}\text { Gunjan et al. }(2015) ; n=60 \\
26 \text { patients (43\%) }\end{array}$ & 22 patients (44 \%) \\
\hline Youngest age & $\begin{array}{l}\text { Pankaj et al. (2015); } \mathrm{n}=100 \\
\quad 30 \text { years }\end{array}$ & 33 years \\
\hline Oldest age & $\begin{array}{l}\text { Pankaj et al. }(2015) ; \mathrm{n}=100 \\
\quad 71 \text { years }\end{array}$ & 70 years \\
\hline Sex & $\begin{array}{l}\text { Pankaj et al. (2015); } \mathrm{n}=100 \\
\text { Male - 74\% } \\
\text { Huang et al. (2018); } \mathrm{n}=157 \\
\text { Male }-63.1 \%\end{array}$ & Male - $74 \%$ \\
\hline Culture growth & $\begin{array}{l}\text { JJ Mendes et al. }(2012) ; n=49 \\
\quad \text { MRSA growth }-24.5 \%\end{array}$ & MRSA growth $-26 \%$ \\
\hline ABPI & $\begin{array}{l}\text { Dhanowar et al. }(2016) ; n=80 \\
A B P I<0.9=12 \text { cases }(15 \%)\end{array}$ & $\begin{array}{c}\mathrm{ABPI}<0.9=16 \text { cases }(32 \\
\%)\end{array}$ \\
\hline & $\mathrm{ABPI}<0.5=2$ cases $(2.5 \%)$ & $\begin{array}{c}\mathrm{ABPI}<0.5=7 \text { cases }(14 \\
\%)\end{array}$ \\
\hline $\begin{array}{l}\text { Arterial Doppler } \\
\text { study } \\
\text { (generalised } \\
\text { narrowing with } \\
\text { arterial block) }\end{array}$ & $\begin{array}{c}\text { Sameer P,Mayur R, Nilay S (2017); } \\
\mathrm{n}=50 \\
10 \text { cases }(20 \%)\end{array}$ & 13 cases (26\%) \\
\hline Rays amputation & $\begin{array}{c}\text { Osaka Kosainekin Hospital (2005); } \\
n=210 \\
110 \text { cases (52 \%) } \\
\end{array}$ & 28 cases (56 \%) \\
\hline \multicolumn{3}{|c|}{ Table 3. Comparison with Other Studies } \\
\hline $\begin{array}{l}\text { RSA - Methicil } \\
\text { ressure Index }\end{array}$ & n Resistant Staphylococcal aure & BPI - \\
\hline
\end{tabular}

In the current study, Table 1, shows that foot gangrene is common in middle aged person i.e., in $4^{\text {th }}$ to $5^{\text {th }}$ decade. Study shows 22 patients ( $44 \%$ ) out of 50 patients were in middle age group i.e., between 41 to 50 years of life compared to a study by Gunjan et al. (2015) conducted in 60 patients in whom, 26 patients ( $43 \%$ ) were in $4^{\text {th }}$ to $5^{\text {th }}$ decade. ${ }^{5}$

On comparing with Pankaj D et al. ${ }^{6}$ study which had a similar age (youngest and oldest) to our study with youngest, 33 years of age and oldest, 70 years of age. In current study, 37 patients (74 \%) were males compared to Pankaj D et al. (2015) study ${ }^{7}$ with $74 \%$ and Huang et al. (2018) study ${ }^{7}$ with $63.1 \%$ male patients. The most common mode of presentation in our study was blackish discoloration of toes / toes with associated cellulitis and ulceration seen in 30 patients (60\%). Most common aetiology leading to foot gangrene in our study was diabetes mellitus with associated arteriosclerosis which frequently led to amputations and was considered as unavoidable complications of diabetes and were classified under 'diabetic gangrene'. 8

On comparing between risk factors and aetiologies, among smoker's (58.8\%) majority had vascular problems and considerable proportions, $35.3 \%$ had diabetes mellitus and all patients with vascular problems had smoking as risk factor. Most common organism isolated from the culture was MRSA, $26 \%$ compared to the study of JJ Mendes et al. (2012) with $24.5 \%$ as MRSA growth in culture. ${ }^{9}$

In our current study, arterial Doppler was done in all study patients and generalised narrowing with arterial block was present in 13 patients (26\%) compared to the study of Sameer P, Mayur R, Nilay S (2017) with 10 patients (20\%). ${ }^{9}$ In our study, on calculating the ABPI value less than 0.9 was present in 16 cases and less than 0.5 in 7 cases compared to Dhanowar et al. (2016) study. ${ }^{10}$ And out of 16 patients 3 has normal Doppler study and remaining 13 patients had abnormal findings which increases the specificity of ABPI.

In our study the most common procedure done for the patients suffering from foot gangrene was Ray's amputation which is $56 \%$ (28 patients) compared to Osaka Kosainekin hospital (2005) which is $52 \% .^{11}$ This is due to the poor glycaemic control and unawareness of the possible complications of foot gangrene in our study patients. After amputation wound healed well.

Another study by Keng Lin Wong et al. (2014) which involved 150 patients, out of whom 106 patients had undergone Ray's amputation and gave a good outcome.12 Petkov et al. study presented the benefits of surgical amputation in management of foot gangrene in diabetes. A well-planned surgical treatment with or without Rays is directly proportional to decrease in total no. of foot amputations. ${ }^{13}$

\section{CONCLUSIONS}

Middle aged men were commonly associated with increased risk of foot gangrene and the commonest aetiology was diabetes with associated risk factor like smoking. The commonest presentation was blackish discoloration of toe $(\mathrm{s})$ along with cellulitis and ulceration. The most common organism isolated in culture was MRSA. Surgical amputation improved the survival rates due to less risk of further limb deterioration which positively impacts the ambulatory status of the patient. Therefore, earlier the intervention greater the opportunity in preventing the disaster. Hence, the foot gangrene study arouses interest as it is challenging as far as the treatment is concerned. In conclusion, high risk patients should be properly educated and effectively managed to reduce the total disease burden and its complications.

Data sharing statement provided by the authors is available with the full text of this article at jemds.com.

Financial or other competing interests: None.

Disclosure forms provided by the authors are available with the full text of this article at jemds.com.

\section{REFERENCES}

[1] John M. Arterial disorders. Chap. 56. In: Williams NS, O'Connell PR, McCaskie AW, eds. Bailey and Love's Short practices of surgery. 27th edn. Boca Ratson: CRC Press 2018: p. 952.

[2] Jain AKC, Viswanath S. Distribution and analysis of diabetic foot. OA Case Reports 2013;2(12):117.

[3] Kalaivani V. Evaluation of diabetic foot complication according to Amit Jain's classification. J Clin Diagn Res 2014;8(12):7-9.

[4] Al Wahbi A. Autoamputation of diabetic toe with dry gangrene: a myth or a fact? Diabetes Metab Syndr Obes 2018;11:255-64.

[5] Das G, Gupta AK, Aggarwal A. Assessment of lower limb arteries by doppler sonography in diabetic patients. Int J Res Health Sci 2015;13(1):18-23.

[6] Pankaj D, Muni S, Jha IN, et al. Clinical presentation and bacteriological profile of diabetic foot infections in Eastern Bihar, India. Int J Res Med Sci 2015;3(11):305864.

[7] Huang YY, Lin C, Yang HM, et al. Survival and associated risk factors in patients with diabetes and amputations caused by infectious foot gangrene. J Foot Ankle Res 2018;11:1. 
[8] Parikh SG, Rabari MG, Shah NJ. Role of arterial doppler in management of diabetic foot. Natl J Integr Res med 2017;8(3):62-7.

[9] Mendes JJ, Marques-Costa A, Vilela C, et al. Clinical and bacteriological survey of diabetic foot infections in Lisbon. Diabetes Res Clin Pract 2012;95(1):153-61.

[10] Dhanowar RK, Nath L, Tiwari PK. A clinical study of peripheral vascular disease in diabetes mellitus with special reference to Ankle Brachial pressure index and color doppler ultrasonography. International Journal of Contemporary Medical Research 2016,3(7):1899-1901.
[11] Miyajima S, Shirai A, Yamamoto S, et al. Risk factors for major limb amputations in diabetic foot gangrene patients. Diabetes Res Clin Pract 2006;71(3):272-9.

[12] Wong KL, Nather A, Chanyarungrojn AP, et al. Clinical outcomes of ray amputation in diabetic foot patients. Ann Acad Med Singap 2014;43(8):428-32.

[13] Petkov R, Gavrailov M, Gavrailov N, et al. Surgical treatment of the diabetic septic foot. Khirurgiia (Sofiia) 2004;60(2):22-4. 